\title{
The Growth Pattern and Structure of Callus from the Red Alga Laurencia sp. (Rhodophyta, Ceramiales) Compared to Shoot Regeneration
}

\author{
R. R. Robaina, P. García-Jimenez and A. Luque ${ }^{1}$ \\ Departamento de Biologia, Universidad de Las Palmas G. C., Box 550 Las Palmas G. C., Canary Islands, Spain
}

(Accepted 25 May 1992)

\begin{abstract}
The occurrence of several forms of disorganized growth (filamentous, groups of cells and compact cell masses) has been reported in seaweed tissue culture as callus or callus-like, and in nature as galls, tumours or callus. Laurencia sp. formed callus in culture. To know whether callus or callus-like types of growth also occurred during regeneration, calluses were induced in explants, excised and cultivated separately. The growth pattern followed by these calluses and their main structural features, revealed by light and electron microscopy, were compared with those occurring on shoot regenerating explants in culture, and in wounded thallus regenerating in nature. Callus occurred as a compact cell mass at the proximal edge of the explants, bearing morphogenetic potential to regenerate shoots. The callus shared structural features with cells or group of cells from which shoots sprout in shoot-regenerating explants in culture. No callus, nor group of cells resembling callus, were seen in thallus regenerating in nature only shoot regeneration was observed.
\end{abstract}

\section{Introduction}

Callus and callus-like formations have been reported in tissue culture of red, brown and green algae (PolneFuller et al. 1986, Saga et al. 1986, Polne-Fuller and Gibor 1987, Robaina et al. $1990 \mathrm{a}, \mathrm{b})$. They are described as a disorganized tissue (filamentous, compact cell masses, group of cells, etc.), which grows spontaneously from the cultivated seaweeds (Fries 1980, Chen 1982, Apt 1984, Polne-Fuller and Gibor 1984, Polne-Fuller et al. 1984, Chen 1987). The causes of callus induction in tissue cultures of algae require more investigation as the role played by plant growth regulators is obscure.

In higher plants, Yeoman and Forche (1980) pointed out the structural similarity between natural and tissue culture derived callus, which lead them to be

\footnotetext{
1 Present address: Duke University Marine Laboratory, Beaufort NC 28516, U.S.A.
}

considered as tissues induced by similar causes which are released (nature) or supplement (in vitro) plant growth regulators.

Observations on the occurrence of galls in algae have been made since 1819 (Merola 1956). As reviewed by Apt (1988), algal galls, callus or tumours in nature seem to be induced mainly by infective bacteria, fungi, animals or algae, in ways which are still little understood. Several authors reported the induction of callus previous to bud regeneration (wound effect) in seaweeds (Felicini and Perrone 1972, Lobban et al. 1985.

In a previous work (Robaina et al. 1990 a) we reported callus induction and bud (small new shoots) regeneration in tissue cultures of the red seaweed Laurencia sp. The present work studied the growth pattern and structure of callus compared to regeneration in culture and nature. The aim was to know whether callus also occurred there and thus 'natural' causes would contribute to callus induction in culture. 


\section{Material and Methods}

\section{Explant and callus culture}

Laurencia sp. an intertidal algae similar to Laurencia obtusa (Hudson) Lamoroux was collected in Gran Canaria (Canary Islands). Voucher specimens are deposited in the herbarium of the Jardin Canario, Gran Canaria, Canary Islands, Spain as sheet LPA 30. Two hours after collection, apical secondary branches were excised from healthy epiphyte-free thalli. The branches were cleaned by previously described methods (Robaina et al. 1990a). After cleaning, the branches were cut again to obtain cylinder-shaped explants $(0.5 \mathrm{~cm}$ long). We marked distal and proximal poles in the explants simply by cutting them in different ways at the ends of the cylinder ( 90 or 45 angle relative to the main axis). This was varied at the ends to avoid the effect of different cutting (i.e. $90^{\circ}$ at the distal, $45^{\circ}$ at the proximal in one replicate, $45^{\circ}$ at the distal and $90^{\circ}$ at the proximal in the next one).

The explants (approx. 500 in number) were cultivated in Petri dishes (15 explants in each) with $20 \mathrm{~mL}$ of solid $(0.8 \%$ agar) PES (Provasoli 1968) culture medium. The culture medium was sterilized by autoclaving $20 \mathrm{~min}$ at $120^{\circ} \mathrm{C}$. After sterilization the medium was supplemented with vitamins (Provasoli 1968) and $50 \mu \mathrm{M}$ germanium dioxide (Aldrich), $20 \mu \mathrm{M}$ ampicillin (Sigma) and $2 \mu \mathrm{M}$ Nystatin (Sigma). The cultures were incubated at $20 \pm 2{ }^{\circ} \mathrm{C}$ in a growth chamber adjusted to a day length of $18: \overline{6}, \mathrm{~L}: \mathrm{D}$ and $27 \mu \mathrm{mol} \mathrm{m}^{-2} \mathrm{~s}^{-1}$ (daylight, Sylvania Grolux).

After 30 days of culture 141 calluses were excised from the basal edge of cultivated cylinder-shaped explants. Calluses (14 to 21 in a Petri dish) were cultivated on solid ( $0.8 \%$ agar) PES for 15 days under the same culture conditions as were used for explant cultures.

Since most of calluses regenerated shoots when still attached to the explant or as soon as they were cultivated separately, we quantified shoot production. Quantification was made using the indices 'number of shoots/number of shoot producing calluses' (i.e. number of shoots per shoot producing callus) and 'number of shoots/total number of calluses'.
An increase in agar concentration in the culture medium from $0.8 \%$ to $1.5 \%$ increased callus induction and reduced morphogenesis in explants from Laurencia sp. (Robaina et al. 1990 a). Fourteen calluses were cultivated in PES $+1.5 \%$ agar to test if the increase in agar concentration would sustain callus growth and avoid shoot production.

\section{Regeneration in situ}

Regeneration in nature was studied by cutting with scissors the main axes of thalli within a $15 \times 15 \mathrm{~cm}^{2}$ area of a natural algal bed (ca. 3000 thalli, $20 \mathrm{~g}$ fresh weight). After 30 days, regenerating thalli were transferred to the laboratory and processed as described below.

\section{Microscopy}

Explants, calluses and thalli were fixed in $2.5 \%$ glutaraldehyde $(\mathrm{v} / \mathrm{v})$ in $0.1 \mathrm{~m}$ sodium cacodylate buffer, containing $0.3 \mathrm{M} \mathrm{NaCl}(\mathrm{pH} 7.4)$ for 4 hours at room temperature. This was followed by washing in the same buffer containing $0.3 \mathrm{M} \mathrm{NaCl}(2 \times 30$ minutes $)$. The specimens were processed through an ethanol series and embedded in glycol methacrylate (GMA, Historesin $^{\mathrm{TM}}$, Reichert-Jung, Gerrids and Smid 1983). Sections $(5 \mu \mathrm{m}$ thick) were stained for general morphology and/or specific stained with controls as summarized in Table I. Some samples were postfixed in $2 \%$ osmium tetroxide in $0.1 \mathrm{M}$ cacodylate buffer, $0.3 \mathrm{M}$ $\mathrm{NaCl}\left(\mathrm{pH} \mathrm{7.4)}\right.$ for 2 hours at $4{ }^{\circ} \mathrm{C}$, dehydratated in methanol/propylene oxide and embedded in Epon (Luft 1961). Sections $(0.1-0.4 \mu \mathrm{m})$ from an ultramicrotome were stained in 5\% uranyl acetate $20-30$ minutes and examined in a Philips EM 301 transmission electron microscope.

\section{Results}

As expected from previous work on callus induction in Laurencia sp. (Robaina et al. 1990 a), compact and pigmented cell masses were seen in the wounded area of totally or partially depigmented explants after 30 days (Fig. 1). The rest of the cultivated explants bleached, then died or regenerated new shoots ( 2 to

Table I. Histochemical methods.

\begin{tabular}{lll}
\hline Stain & Specificity & References \\
\hline Periodic acid Schiff (PAS) & neutral polisacch. & McCully 1966 \\
Mercury bromophenol blue & proteins & Ruthmann 1966 \\
Alcian blue & sulphated polisacch. & Parker and Diboll 1966 \\
Tolouidin blue & general morphology & Tsekos 1982 \\
Hematoxilin-eosin & general morphology & Troyer and Babich 1982 \\
\hline
\end{tabular}




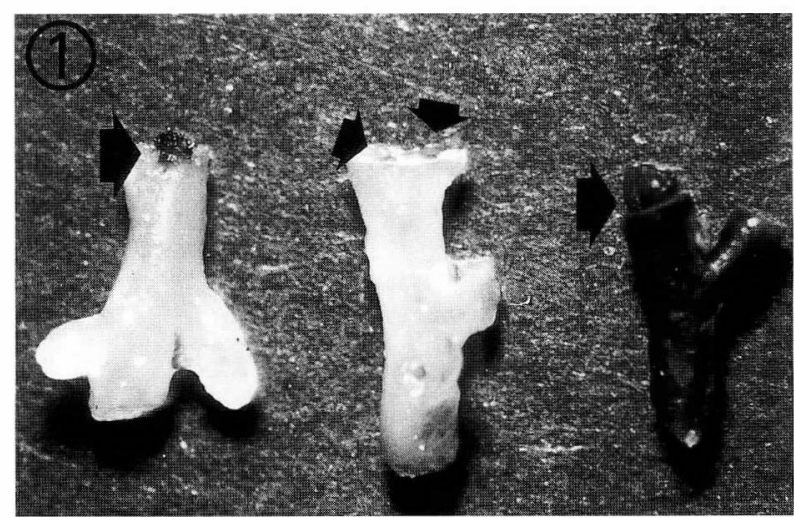

Fig. 1. Callus at the proximal edge (left), shoot regeneration in culture at the distal edge (center) and shoot regeneration in nature (right).

3) at the wounded area (Fig. 1). Fifty five percent of the total cultivated explants showed callus or regenerated shoots (ca. $40 \%$ callus and $60 \%$ shoots).

The distal and proximal edge of the regenerating explants were clearly identified because of the different ways they were cut. The pattern of regeneration was different at each edge, callus induction being mostly located at the proximal edge and shoots regeneration at distal edge (Fig. 1). At the proximal edge, the bigger the wounded area (i.e. larger in oblique cuts than straight cuts) the bigger the callus. Shoot regeneration was the same regardless of the form of the distal edge.

After being excised from explants, or even whilst still attached to them, most of the calluses initiated shoots in PES $+0.8 \%$ agar. This is expressed by the index 'number of shoots/total number of calluses' which increased significantly in 15 days (Table II). Callus did not grow in a disorganized way independently of the callus size after being excised. The smallest calluses did not regenerate shoots so well. Shoot regeneration per shoot producing callus did not vary in 15 days (Table II, Fig. 2).

The calluses cultivated on $15 \mathrm{~g} \mathrm{~L}^{-1}$ agar did not grow as a disorganized cell mass, as expected from the results of callus induction by $1.5 \%$ agar (Robaina $e t$

Table II. Values of the morphogenetic indices observed in callus of Laurencia sp. cultivated for 15 days in PES medium $+0.8 \%$ agar $(\mathrm{n}=14$ to 21 . Number of replicates $=8$ ).

\begin{tabular}{lcc}
\hline Index & Initial value & Value after 15 days \\
\hline $\begin{array}{c}\text { Shoots/total number } \\
\text { calluses }\end{array}$ & $1.63 \pm 0.76$ & $2.54 \pm 0.97\left({ }^{* *}\right)$ \\
$\begin{array}{c}\text { Shoots/shoot pro- } \\
\text { ducing calluses }\end{array}$ & $2.98 \pm 0.61$ & $2.91 \pm 0.79$ n.s. \\
\hline
\end{tabular}

(**) $0.01<\mathrm{P}<0.001$

n. s. non significant
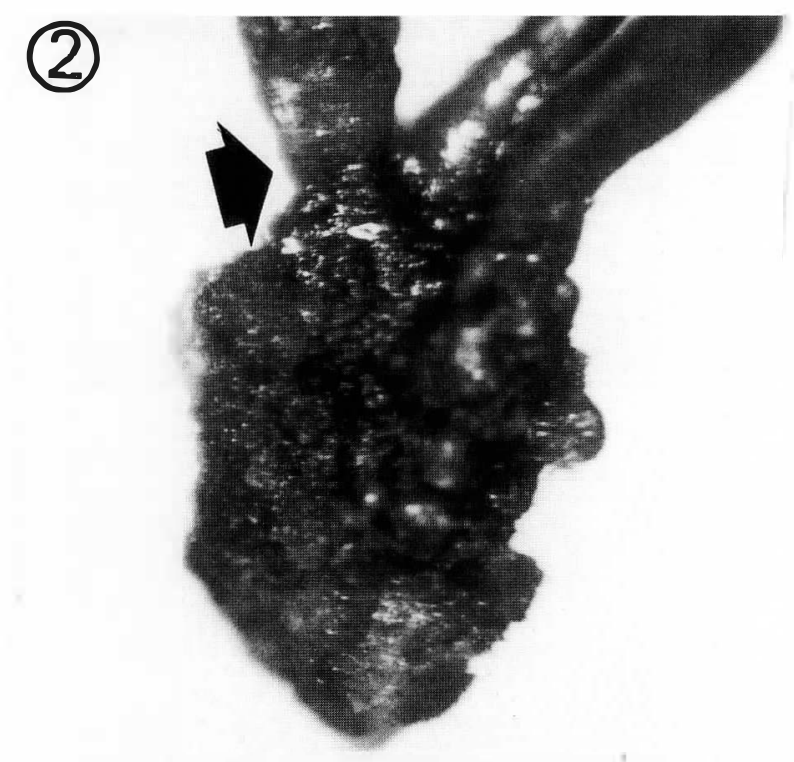

\section{$0.2 \mathrm{~mm}$}

Fig. 2. Morphogenetic callus with 3 shoots (arrow) 30 days after being excised from the explant.

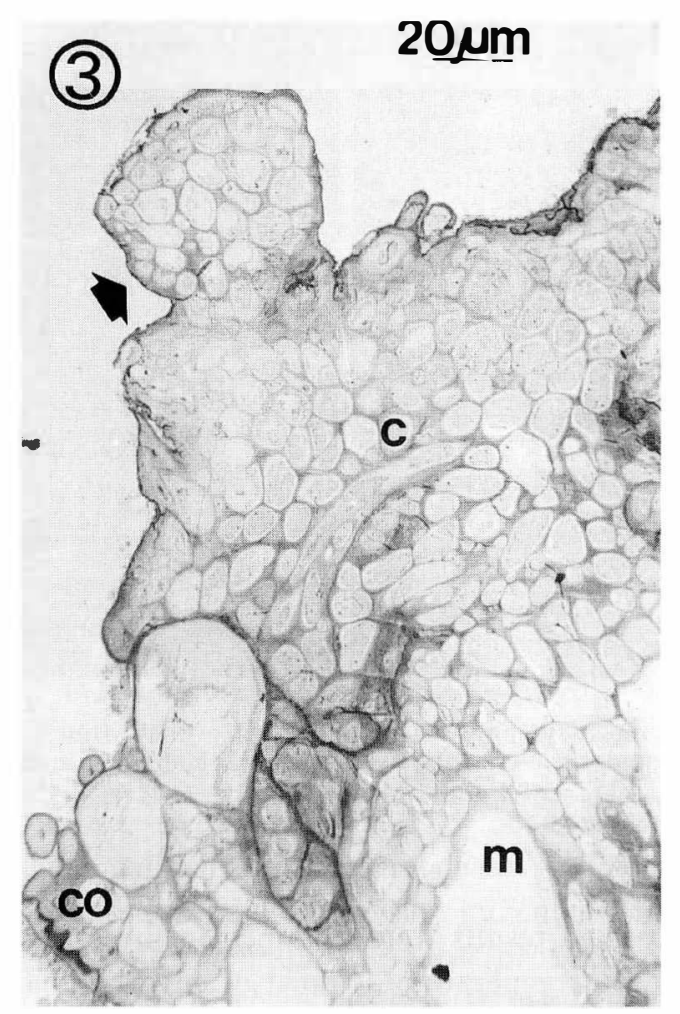

Fig. 3. Section $(5 \mu \mathrm{m})$ of Laurencia sp. callus showing the disorganized distribution of cells in the callus and sprouting shoot (arrow). ( $c$; callus cells, co; cortical cells, $m$; medullary cells).

al. 1990 a). They did not regenerate shoots. Calluses had the same appearance as when excised from the explants. In 30-40 days the calluses turn reddish, then bleached and died. 


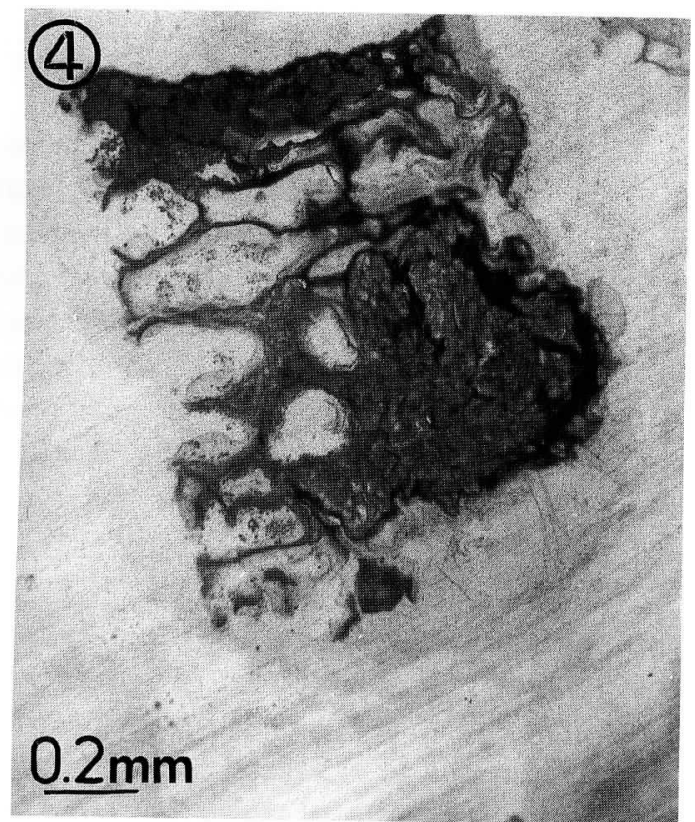

Fig. 4. Section $\left(5^{\prime} \mu \mathrm{m}\right)$ showing starch accumulation in callus cells as revealed by PAS specific staining (dark). Note starch accumulation also in cortical cells of the explant. (Control was amilase treated sections.)
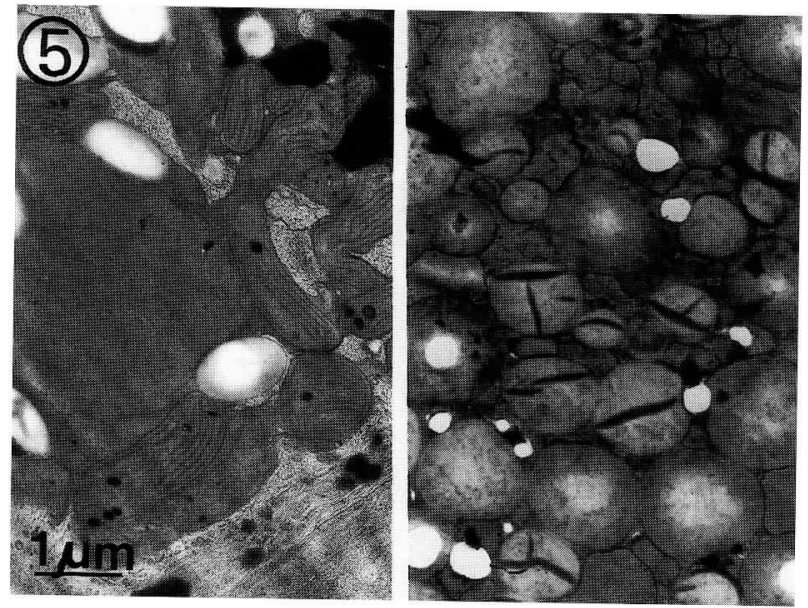

Fig. 5. Transmission electron microscopy of a section $(0.4 \mu \mathrm{m})$. Intracellular content in callus cells. Note the high accumulation of floridean starch grains achieved by the cells (right).

Unexpected results were obtained in the experiment on in situ regeneration as most of cut-thalli had disappeared after 30 days and new thalli substituted for them. Still, we recovered some of them $(20-30$ in number) which only showed regeneration of well developed and pigmented shoots compared to shoot regenerated in culture (Fig. 1). Neither callus nor callus-like structures were seen at the wounded area of the remaining thalli which did not regenerate shoots. Those areas were covered by epiphytes as seen under the stereomicroscope.

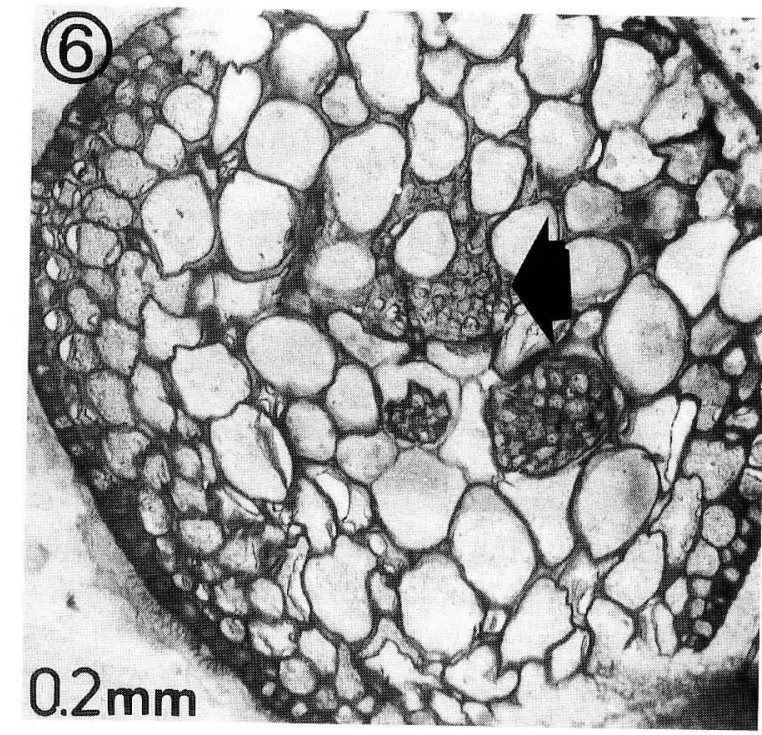

Fig. 6. Disorganized cells (arrow) within intercellular medullary space in shoot-regenerating explant in culture.

The cells in the callus were smaller than medullary cells, similar in size to the cortical cells, but distributed in a disorganized way. In morphogenetic callus the cells seem to form the basal cell layer of the developing shoot (Fig. 3). Compared to bleached and probably dead cells of the explant, cells in the callus kept their intracellular content (protein and large accumulation of grains revealed as starch by PAS and transmission electron microscopy. Fig. 4 and 5).

In shoot regenerating explants we observed a very thin cell layer sharing structural features with the cells in the callus, as they were small cells distributed in a disorganized way in the intercellular space of the bigger medullary cells (Fig. 6).

We could find neither this cell layer nor similar cells in thalli which gave rise to shoots in nature.

\section{Discussion}

In previous works we reported that callus formation in Laurencia sp. is dependent on its cultivation on semi-solid (agar solidified) culture medium (i.e. not seen in explants cultivated in liquid PES. GarciaReina et al. 1988). An increase in agar concentration from 0.3 to $1.5 \%(\mathrm{w} / \mathrm{v})$ increased callus induction (Robaina et al. 1990 a). This alga, as did other algae, appeared to respond to the artificial culture conditions by forming callus. Nevertheless, this work pointed out interesting and rare events in callus induction in $\mathrm{Lau}$ rencia $\mathrm{sp}$. 
Callus induction was polar as its occurrence was higher at the proximal than at the distal edge. This could only be explained if there were differences in cells at the distal and proximal edges (e.g. age, physiological status), which lead the latter to produce callus. A wound effect made 'polar' the callus formation in Pterocladia capillacea (Gmelin) Bornet et Thuret. (Fellicini and Perrone 1972). Wound healing might contribute to callus formation in Laurencia sp. This possibility will be discussed later.

Callus was a morphogenetic tissue since a significant increase in the index "number of shoots/total number of calluses' was observed in 15 days (Table II). Moreover, this morphogenetic development was followed by callus formation after being excised, which means shoot regeneration occurred independently from the explant (Fig. 2). Callus expressed an apparently fixed morphogenetic pattern, which lead to the formation of 2 to 3 shoots per callus in 15 days (shoots/morphogenetic, Table II). Callus was thus able to propagate the thallus. In fact, we have propagated thalli through callus culture to obtain new highly branched thalli (Fig. 7). This is an interesting characteristic of callus from Laurencia sp., as callus was obtained in Gracilaria ferox J. Agardh, and Grateloupia doryphora (Montagne) Howe (filamentous) which did not grow further after being excised (Robaina et al. $1990 \mathrm{a}$ ).

However, callus was not that independent since smaller calluses did not regenerate shoots or grow further after being excised. A 'critical size' of callus seems to be required for the callus to be able to produce shoots after being separated. This 'ciritical size' of callus might be achieved through nourishment from the explants as they bleached and probably released compounds (e.g. nutrients). The fact that explants only regenerated callus or shoot and not both, ought not to be interpreted as the existence of callus or shoot specialized explants, but that explants were not able to support both callus and shoot at the same time. Even more interesting is the possibility that the compound-leaching from the explants not only nourished but also induced callus formation. The genus Laurencia is a well known producer of natural products (Faulkner 1977). We have observed that a water soluble extract from Laurencia sp. increased callus formation (growth) and its morphogenesis (Robaina, unpublished).

Cell structure in callus and their arrangement is different to that in the thallus. Callus cells resembled cortical cells which suggests a cortical origin for the former. As callus cells were initially located at the medullary cell layer, a better explanation would be that inner medullary cells regenerated cortical-like cells to cover the wounded area (Fig. 3).

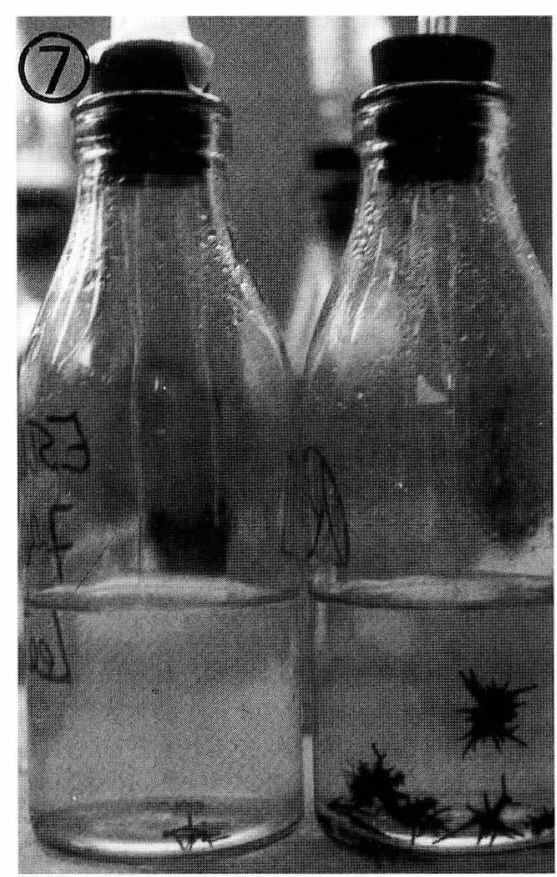

Fig. 7. Thalli from callus after 3 months (right) in liquid PES.

The accumulation of starch in callus cells (Figs 4 and 5) could be due to the storage required to support morphogenesis as it was in other propagative cells or structures in seaweeds (Cole and Sheath 1980, Tsekos 1982, Delivopoulus and Tsekos 1985). The final destination of the accumulated products was not within the scope of this work, thus it remains obscure whether there is a cause-effect relationship between morphogenetic potential and cell morphology and contents in the callus. Since starch was also observed in cortical cells of the explants (Fig. 4), its accumulation in callus cells could be simply due to the artificial influence of culture.

The existence of a microscopical disorganized cell layer in shoot regeneration at the distal edge of the explants, and the similarity observed between callus and that cell layer (compare Figs 2 to 6) suggests a wound effect origin for both. The fact that neither callus nor callus-like structures were observed in shoot-regenerating thalli in nature indicates some effect of the culture conditions. Most probably callus was induced (just triggered at the distal and enhanced at the proximal edge) by wound healing.

Other causes should not be discarded. However, the implication of contaminants in callus induction in Laurencia sp. (Apt 1988) is unlikely since, if this inductive contaminant was present then all of the callus-forming explants $(40 \%$ of the regenerating explants) had to be contaminated. Moreover, the assumption of a rare specific contamination at the prox- 
imal edge only would be required in order to explain the polarity in callus formation.

In conclusion, explants of Laurencia sp. cultivated on solid culture medium (agar solidified) regenerated shoots at the proximal edge through a compact cell mass, the callus. Originally it is formed by a wound effect in culture, but it develops into a propagule with a marked independence and morphogenetic capability and characteristics.

\section{References}

Apt, K. E. 1984. Callus-like growths of Gracilaria epihippisora Hoyle (Rhodophyta). J. Phycol. 20: 138.

Apt, K. E. 1988. Galls and tumour-like growths on marine macroalgae. Dis. Aquat. Org. 4: 211-217.

Chen, L. C. M. 1982. Callus-like formation from Irish moss. Biological Bulletin National Taiwan Normal University. pp. $63-67$.

Chen, L. C. M. 1987. Protoplast morphogenesis of Porphyra leucosticta in culture. Bot. Mar. 30: 399-403.

Cole, K. and R. G. Sheath. 1980. Ultrastructural changes in major organelles during spermatial differentiation in Bangia (Rhodophyta). Protoplasma 102: 253-279.

Delivopoulus, S. G. and I. Tsekos. 1985. Ultrastructure of the fusion cell in Gracilaria verrucosa (Huds.) Papenfuss (Rhodophyta, Gigartinales). New Phytol. 101: 605-612.

Felicini, G. P. and C. Perrone. 1972. Sulla formazione di galle nella rigenerazione di Pterocladia capillacea (Gmel.) Born. et Thor. in coltura. Giornale Botanico Italiano 106: $351-$ 358.

Fries, L. 1980. Axenic tissue culture from the sporophytes of Laminaria digitata and Laminaria hyperborea (Phaeophyta). J. Phycol. 16: 475-477.

Faulkner, J. D. 1977. Interesting aspects of marine natural products chemisty. Tetrahedron 33: $1421-1443$.

Garcia-Reina, G., R. Robaina and A. Luque. 1988. Regeneration of thalliclones from Laurencia sp. (Rhodophyta). In: (M. S. S. Pais, F. Mavituna and F. Novais, eds) Plant Cell Biotechnology. Springer-Verlag, Berlin. pp. 81-86.

Gerrids, P. O. and L. Smid. 1983. A new, less toxic polimerization system for the embedding of soft tissues in glycol methacrylate and subsequent preparing of serial sections. $J$ of Microscopy 132: $81-85$.

Lobban, C. S., P. J. Harrison and M. J. Duncan. 1985. The Physiological Ecology of the Seaweeds. Cambridge University Press, New York. pp. 105-109.

Luft, J. H. 1961. Improvements in epoxy resin embedding methods. J. Biophys. Biochem. Cytol. 9: 409-414.

McCully, M. E. 1966. Histological studies on the genus Fucus. I. Light microscopy of mature vegetative plant. Protoplasma 62: $287-305$.

Merola, A. 1956. Le galle nelle alghe. Annali Di Botanica 25: $260-281$.

Parker, B. C. and A. G. Diboll. 1966. Alcian stains for hystochemical localization of acid and sulphated polysacharides in algae. Phycologia 6: 37-46.

Polne-Fuller, M. and A. Gibor. 1984. Developmental studies in Porphyra. I. Blade differentiation in Porphyra perforata as expressed by morphology, enzymatic digestion, and protoplast regeneration. J. Phycol. 20: 609-616.

Polne-Fuller, M. and A. Gibor. 1987. Calus and callus-like growth in seasweeds: induction and culture. Hydrobiologia 151/152: $131-138$.

Polne-Fuller, M., M. Biniaminov and A. Gibor. 1984. Vegetative propagation of Porphyra perforata. Hydrobiologia 116/ 117: $308-313$.

Polne-Fuller, M., N. Saga and A. Gibor. 1986. Algal cells, callus, and tissue cultures and selection of algal strains. Beihefte Zur Nova Hedwigia 83: 30-36.

Provasoli, L. 1968. Media and prospects for the cultivation of marine algae. In: (A. Watanabe and A. Hattori, eds) Cultures and Collections of Algae. Japanese Society of Plant Physiologist. pp. $63-67$.

Robaina, R. R., G. Garcia-Reina and A. Luque. 1990 a. The effects of the physical characteristics of the culture medium on the development of red seaweeds in tissue culture. $\mathrm{Hy}$ drobiologia 204/205: 137-142.

Robaina, R. R., P. García, G. García-Reina and A. Luque. 1990 b. Morphogenetic effect of glycerol on tissue cultures of the red seaweed Grateloupia doryphora. Journal Applied Phycology 2: 137-143.

Ruthmann, A. 1966. Methoden der Zellforschung. Franckh'sche Verlagshandlung. W. Keller and Co. Stuttgart.

Saga, N., M. Polne-Fuller and A. Gibor. 1986. Protoplasts froom seaweeds: production and fusion. Beihefte Zur Nova Hedwigia 83: $37-43$.

Troyer, H. and E. Babich. 1981. A hematoxylin and eosin-like stain for glycol methacrylate embedded tissue sections. Stain Technology 56: 39.

Tsekos, I. 1982. Plastid development and floridean starch grain formation during carposporogenesis in the red algae Gigartina teedii. Cryptogamie Algologie 3: 91-103.

Yeoman, M. M. and E. Forche. 1980. Cell proliferation and growth in callus cultures. In: (I. K. Vasil, ed.) International Review of Cytology. Perspectives in Plant Cell and Tissue Culture. Academic Press, New York. pp. 1-21. 